Leading article/Uvodnik

\title{
No health without workforce, no workforce without nurses and midwifes
}

\author{
Ni zdravja brez delovne sile, ni delovne sile brez medicinskih sester in babic
}

\author{
Judith Shamian, Peter Požun
}

As the $27^{\text {th }}$ President of the International Council of Nurses (ICN), Dr. Judith Shamian was privileged to visit Slovenia and Croatia in October 2015 and meet with some of the ICN National Nursing Associations (NNAs) in Region 3.

ICN has over 130 NNA members and speaks on behalf of the 16 million nurses worldwide. Their concerns and activities are broad, including issues related to regulation, professional practice, and socio economic welfare, just to mention a few.

Their 2014-2018 Strategic Plan has a strong focus on making sure that the nursing agenda is addressed both within the nursing community and outside of the nursing community.

Her experience during her visit to Slovenia reinforced the impact nurses can have on national policy, nursing practice and the health of the people when nursing works within the nursing community and partners with government and other organisations.

In her comments, she would like to reflect on her observations in relation to three of the four themes of the ICN 2014-2018 Strategic Plan:

1. Global Voice: the goal is "to bring solidarity and cooperation across the profession in collaboration with other stakeholders".

Throughout her visit in Slovenia, she had the opportunity to meet with members of the NNA, members of the various nursing organisations and sectors, and Government officials. It is clear that there are open channels of communication within nursing and with other stakeholders. Global Voice does not mean that there is always agreement on every topic but there is solidarity and respect. Efforts are made to work together on issues that matter. She was reassured to see that such a condition exists in Slovenia, which is an enabler to work together. Unfortunately, in many of the countries, nursing organisations do not necessarily understand the importance of solidarity for the overall goal to advance health and nursing.

2. Strategic Leadership: the goal is "to provide strategic leadership to empower nurses and nursing organisations to advance nursing worldwide through coherent, efficient, effective and judicious advocacy by and for nurses, nursing and health".

While Global Voice is the foundation for working together, in order to have solidarity it is not sufficient. The Global Voice is the way to come to agreement on the issues that need to be dealt with and build a strategy to do so. To have Strategic Leadership is hard for many reasons: nurses, the majority of whom are women, far too often are not confident and/or assertive to "push" their agenda; nursing is often not considered as a profession which is included in high level discussions and decision making and we are not schooled in the art and the science of leadership. In spite of this, nurses understand the importance of Strategic Leadership. It is evident that in order to change and move the health and the nursing agenda they need to take the Global Voice and use our Strategic Leadership to move that agenda forward. In her visit to Slovenia, and later on participating in the meeting of the Region 3 NNAs in Croatia, it was clear that Strategic Leadership is being built in the region. It is not easy; all of the countries in the region have undergone enormous changes in our lifetime that requires learning about different styles of governments and learning how to have a voice and how to lead in them. Some of the countries have experienced bitter and tragic internal conflicts and some political challenges are still under way. Despite this, there is clear evidence that strategic leadership by nurses and nurse leaders is in place. There has been significant evolution of nursing education and there has been the establishment of nursing organisations. Structures have been established, for example

Judith Shamian, PhD, RN, LLD (hon), D.Sci (hon), FAAN, President, International Council of Nurses

Peter Požun, Msc (manag), Bsc (econ), RN, Board of Directors, International Council of Nurses

Correspondence e-mail/Kontaktni e-naslov: peter.pozun@siol.net 
in Slovenia, where there are organised nursing committees as part of governments reporting to the Minister of Health advising on health and nursing issues. And she personally experienced the leadership of the men and women she has met.

As ICN works in partnership with their members and as they focus on key areas that need change, the importance of Strategic Leadership becomes more and more important. Leadership is a science and an art that is learned. One becomes good at it by knowing the art and the science and by stepping forward and practicing the needed strategic leadership. Any meaningful change is a journey; sometimes it is a long journey, but having a "global voice" and "strategic leadership" are two very important ingredients.

3. Policy impact: the goal is "to influence the design and implementation of policy in health and other related areas to achieve better health outcomes".

This is the "punch line" as they say, this is why having a global voice and strategic leadership is so important. Having a global voice and strategic leadership can lead to valuable contributions and can help in building support to issues within and outside of the nursing community, but having all that without policy impact is like having very good soccer players on the field but they never score a goal. Having policy impact is the way by which they will change reality. What she has seen and heard in Slovenia is that the majority of the people delivering nursing care are still secondary school educated. By all standards, this is not the recommended workforce both from the quality care aspect and the individuals who give the care perspective. In Slovenia there are fewer Registered Nurses (RNs) $(n=5,711)$ than physicians $(n=6,242)$ and there are just $2.33 \mathrm{RNs}$ per 1,000 population. These paradoxical figures are not consistent with any global normative recommendations.

There are many studies like the RN4Cast (European Commission, 2015), studies by Aiken and colleagues $(2003 ; 2011)$ that recognise conclusively the need to have well prepared nurses in order to give the best care and increase the chances for patients to stay alive and recover quickly. The author is sure that the high school educated workforce are very nice group of boys and girls, but they are boys and girls far too young to be exposed to complex work and far too young to understand the physiological and psychosocial aspect of care that is required. Furthermore, 15-19 year olds need the opportunity to shape and learn their own personality and identity; to expose them and expect them to try to learn to become a healthcare professional is not conducive for their development. Both the European directive (ED) (European Commission, 2005), and the practice in the OECD (Organisation for Economic Co-operation and Development) countries indicate the need for university level preparation. So the question and the challenge is how to have a policy impact and change the current Slovenian reality using human resources as one example.
On the occasion of the Regional Summit held in Opatia, Croatia the representatives of the National Nurses Associations of Croatia, Macedonia, Montenegro, Serbia and Slovenia have accepted this declaration:

"We, the nurses and midwives from the above countries in ICN's Region 3, have encountered many similarities regarding education, competencies, employment and working conditions in which we practice nursing. Our patients have equal human rights, one of which is the right to accessible, safe healthcare services in accordance to their needs.

Evidence in Europe and many other regions demonstrates that, in order to serve our citizens at their time of need, we must have nurses with university level education who provide professional, quality and effective care in the best interest of patients. We recommend to our governments to take all the necessary actions to transform the education system in order to educate nurses and midwives responsible for delivering nursing care at university programmes which are harmonized with EU Directives and demonstrated by research as being the proper level of preparation for quality patient care.

For the nurses and midwives who were educated at the level of secondary vocational schools, we wish to provide the opportunity to obtain additional knowledge, in order that they can achieve university level education, which could be achieved through implementation of the 'bridging programmes' within the framework of academic public institutions.

We are calling on the governments to work with nursing organisations to develop and implement a plan to transform the education of nurses and to invest or/ and seek the necessary financial resources from existing state budgets or EU Community funds for realisation of these programmes.

Furthermore, for the public interest, we call upon state officials to put stronger efforts into the process of legislation and put forward the Nursing Act and Midwifery Act in order to regulate the nursing and midwifery professions" (International Council of Nurses, 2015).

In conclusion, she thanked for the privilege to have the opportunity to visit Slovenia and see first-hand how well the Slovenians live the ICN's Strategic Plan of 2014-2018. She also extended her congratulations for the great progress and accomplishments achieved. She expressed every good wish that the contribution of nurses to the health of the Slovenian population and to nursing be continued.

\section{Slovenian translation/Prevod v slovenščino}

Dr. Judith Shamian, sedemindvajseta predsednica Mednarodnega svetamedicinskih sester-International Council of Nurces (ICN), je imela v oktobru 2015 čast obiskati Slovenijo in Hrvaško, kjer se je srečala z 
nekaterimi predstavniki in predstavnicami nacionalnih združenj medicinskih sester v okviru 3. regije.

Mednarodni svet medicinskih sester vključuje preko 130 nacionalnih združenj medicinskih sester in združuje 16 milijonov medicinskih sester $\mathrm{z}$ vsega sveta. Opravlja številne naloge in aktivnosti, ki zadevajo regulacijo poklica, strokovno delo, socialnoekonomsko blagostanje in drugo.

Strateški načrt ICNa za obdobje 2014-2018 posveča posebno pozornost temu, da so aktualne vsebine $s$ področja zdravstven nege obravnavane tako znotraj kot tudi izven zdravstvene nege.

Obisk dr. Judith Shamian je okrepil vpliv, ki ga lahko imajo medicinske sestre na oblikovanje nacionalne politike, na delo $s$ pacientom in ob njem ter na zdravje prebivalstva, še posebej kadar so prizadevanja medicinskih sester in sodelavcev usklajena $\mathrm{z}$ vladnimi in drugimi organizacijami. V prispevku predstavlja svoja opažanja, ki zadevajo tri od štirih področij Strateškega načrta ICN za obdobje 2014-2018.

1. Globalni glas svetá, katerega cilj je vzpostaviti solidarnost in sodelovanje med poklicnimi skupinami in sodelovanje $\mathrm{z}$ ostalimi deležniki $\mathrm{v}$ zdravstvenem varstvu.

Med obiskom v Sloveniji se je dr. Judith Shamian srečala $s$ predstavniki in predstavnicami Zbornice zdravstvene in babiške nege - Zveze društev medicinskih sester, babic in zdravstvenih tehnikov Slovenije, člani različnih strokovnih teles $\mathrm{v}$ zdravstveni negi in sektorjev ter vladnimi predstavniki. Po njeni oceni je komunikacija med medicinskimi sestrami in drugimi deležniki v Sloveniji dobra. Globalni glas svetá ne pomeni, da se sogovorniki o vseh temah vedno strinjajo, nujna pa je vzajemna solidarnost in spoštovanje ter sodelovanje na življenjsko pomembnih področjih. V Sloveniji obstajajo vsi pogoji za tako sodelovanje. Žal pa opaža, da v mnogih drugih državah združenja medicinskih sester ne prepoznavajo ključnega pomena solidarnosti za doseganje boljšega zdravja prebivalstva in napredne zdravstvene nege.

2. Strateško vodenje, katerega cilj je medicinskim sestram in organizacijam zdravstvene nege zagotoviti potrebno moč razvijati zdravstveno nego v širšem globalnem okolju, ki temelji na povezanem, učinkovitem, storilnem in preudarnem zagovorništvu medicinskih sester za medicinske sestre, za zdravstveno nego in za zdravje.

Cetudi je Globalni glas svetá temelj skupnega dela, ne more v celoti zagotoviti solidarnosti. Predstavlja le način, kako doseči soglasje in razviti strategije reševanja določenih problemov. Strateško vodenje ni enostavno, saj so strokovnjaki na področju zdravstvene nege večinoma ženske, ki jim primanjkujeta samozaupanje in odločnost pri uresničevanju ciljev. Poleg tega se strokovnjaki zdravstvene nege premalo vključujejo $\mathrm{v}$ visoko strokovne razprave in odločanje. Dr. Judith Shamian zaznava problem tudi v tem, da je v izobraževanju medicinskih sester premalo izraženo razvijanje vodilnih in vodstvenih kompetenc. Kljub naštetemu pa se medicinske sestre zavedajo pomembnosti strateškega vodenja. Globalni glas svetá in Strateško vodenje predstavljata temelj za spremembe in izboljšanje zdravja ter uresničevanje ciljev zdravstvene nege. Med svojim obiskom $\mathrm{v}$ Sloveniji in udeležbo na kongresu hrvaškega nacionalnega združenja medicinskih sester se je dr. Judith Shamian prepričala, da se strateško vodenje $\mathrm{v}$ teh regijah uresničuje. Proces uvajanja strateškega vodenja zahteva pripravljenost in mnogotere napore pri sprejemanju novosti in načinov vodenja ter uveljavljanju strokovnih prepričanj. Nekatere države so doživljale grenka in tragična notranja nesoglasja in nekatere politične spremembe še niso dorečene in privzete. Kljub temu je zaznati, da medicinske sestre izvajajo strateško vodenje in se uveljavljajo kot vodje. Izobraževanje medicinskih sester sledi razvoju znanosti in stroke in večje je tudi število formalno organiziranih združenj medicinskih sester. V Sloveniji društva (združenja), strokovna telesa in različne delovne skupine $\mathrm{v}$ zdravstveni negi sodelujejo z Ministrstvom za zdravje teri sooblikujejo priporočila in smernice na področju zdravja in zdravstvene nege. Dr. Judith Shamian se je osebno seznanila z vodilnimi strokovnjaki in strokovnjakinjami na področju zdravstvene nege.

Sodelovanje ICN s svojimi članicami na ključnih področjih, ki zahtevajo spremembe, dokazuje pomembnost strateškega vodenja. Vodenje je znanost in umetnost, ki ju je potrebno usvojiti. Dober vodilni delavec mora imeti potrebna znanja in pogum, da strateški načrt izvaja. Vsaka namenska sprememba je kot potovanje, včasih celo dolgo potovanje, kjer pa sta glas sveta in strateško vodenje ključna dejavnika.

3. Vpliv politike, katere cilj je oblikovati in izvajati politiko smernice $\mathrm{v}$ zdravstvu in drugih povezanih področjih, da bi zagotovili boljše zdravje populacije.

Glas sveta in strateško vodenje sta ključna $\mathrm{za}$ doseganje teh ciljev in predstavljata ustrezno podporo, tako strokovnjakom na področju zdravstvene nege kot tudi drugim. Dr. Judith Shamian pa poudarja tudi pomen ustrezne politike, brez katere ne more biti želenega uspeha. V prispodobi bi lahko rekli, da brez političnega vpliva ostajamo kot dobri igralci nogometa, ki nikoli ne zadenejo gola. Imeti politični vpliv je pot, s katero lahko spremenimo realnost. $\mathrm{V}$ Sloveniji zdravstveno nego v pretežni meri izvajajo srednješolsko izobraženi kadri, kar je po vseh sprejetih standardih neprimerno. Srednješolska izobrazba je neustrezna $\mathrm{z}$ vidika kakovosti opravljenega dela kot tudi $\mathrm{z}$ vidika izvajalcev zdravstvene nege. $\mathrm{V}$ Sloveniji je manj diplomiranih medicinskih sester in zdravstvenikov $(n=5711)$ kot zdravnikov $(n=6242)$ in delež diplomiranih medicinskih sester na 1000 prebivalcev je le 2,33. Ta paradoksalna razmerja so $\mathrm{v}$ močnem razkoraku s priporočenimi standardi in normativi. 
Številne raziskave, med njimi tudi RN4Cast (European Commission, 2015) in raziskave Linde Aiken in sodelavcev $(2003 ; 2011)$, ugotavljajo, da je dobra usposobljenost medicinskih sester nujen pogoj za izvajanje visokokakovostne zdravstvene nege, ki pripomore $\mathrm{k}$ hitrejšemu okrevanju in ohranjanju življenj. Po mnenju dr. Judith Shamian so srednješolci v zdravstveni negi tudi premladi za izvajanje kompleksnih nalog, ki zahtevajo fiziološko in psihološko zrelost. Prezgodnje prevzemanje strokovnih zadolžitev lahko ovira uspešen razvoj posameznikove osebnosti in identitete $\mathrm{v}$ času adolescence. Evropska direktiva (European Commission, 2005) in izkušnje v državah OECD (Organizacija za gospodarsko sodelovanje in razvoj) narekujejo nujnost univerzitetne izobrazbe strokovnjakov na področju zdravstvene nege. Slovenijo torej čaka izziv, kako udejanjiti zdravstveno politiko in spremeniti trenutne razmere $\mathrm{z}$ bolj kompetentnimi človeškimi viri.

Med zasedanjem regionalnega vrha $\mathrm{v}$ Republiki Hrvaški, ki je potekalo v Opatiji, so predstavniki nacionalnih združenj medicinskih sester iz Hrvaške, Makedonije, Črne gore, Srbije in Slovenije sprejeli naslednjo deklaracijo:

"Medicinske sestre in babice prej navedenih držav 3. regije ICN se srečujemo z mnogimi podobnostmi na področju izobrazbe, kompetenc, zaposlovanja in pogojev dela, $v$ kakršnih izvajamo zdravstveno nego. Naši pacienti imajo enake človekove pravice in ena od teh je pravica do dostopnih in varnih storitev zdravstvenega varstva skladno $z$ njihovimi potrebami.

$V$ Evropi in mnogih drugih regijah podatki kažejo, da potrebujemo medicinske sestre $z$ univerzitetno izobrazbo, ki zagotavljajo profesionalno, kakovostno in učinkovito zdravstveno nego $v$ dobro pacientov. Vladam priporočamo, da spremenijo izobraževalne sisteme tako, da se medicinske sestre in babice, odgovorne za izvajanje zdravstvene in babiške nege, lahko izobražujejo na univerzitetnih programih, usklajenih $z$ direktivami Evropske unije, ki se skozi raziskave kažejo kot ustrezna raven priprave za kakovostno zdravstveno obravnavo pacientov.

Medicinskim sestramin babicame, ki so seizobraževale na srednjih strokovnih šolah, želimo zagotoviti priložnost, da pridobijo dodatna znanja, s katerimi lahko dosežejo univerzitetno izobrazbo. To bi bilo moč doseči skozi implementacijo 'prehodnih programov' znotraj javnih akademskih institucij.
Vlade pozivamo $k$ sodelovanju $z$ organizacijami $z$ dravstvene nege pri razvoju in uveljavitvi načrta $z a$ spremembo izobraževanja medicinskih sester, in da za realizacijo teh programov prispevajo potrebna finančna sredstva ali jih zagotovijo $v$ državnih proračunih oziroma skladih Europske unije.

$V$ interesu javnosti tudi pozivamo visoke državne funkcionarje, da vložijo več truda $v$ zakonodajni postopek in sprejmejo Zakon o zdravstveni negi in Zakon o babištvu, ki regulirata poklice $v$ zdravstveni negi in babištvu (International Council of Nurses, 2015).

Ob zaključku svojega obiska v Sloveniji je dr. Judith Shamian izrazila svoje zadovoljstvo in čestitala prisotnim za velik napredek in dosežke pri izvajanju Strateškega načrta ICNa, za obdobje 2014-2018. Svoj prispevek zaključuje z željo, da strokovnjaki zdravstvene nege nadaljujejo s svojim prispevkom za ohranjanje zdravja prebivalcev Slovenije in razvijanjem stroke zdravstvene nege.

\section{Literature/Literatura}

Aiken, L.H., Clarke, S.P., Cheung, R.B., Sloane, D.M. \& Silber, J.H., 2003. Educational levels of hospital nurses and surgical patient mortality. JAMA, 290(12), pp. 1617-1623.

http://dx.doi.org/10.1001/jama.290.12.1617

PMid:14506121; PMCid:PMC3077115

Aiken, L.H., Cimiotti, J.P., Sloane, D.M., Smith, H.L., Flynn, L. \& Neff, D.F., 2011. Effects of nurse staffing and nurse education on patient deaths in hospitals with different nurse work environments. Medical Care; 49(12), pp. 1047-1053. http://dx.doi.org/10.1097/MLR.0b013e3182330b6e PMid:21945978; PMCid:PMC3217062

European Commission, 2005. Directive 2005/36/EC of the European Parliament and of the Council of 7 September 2005 on the recognition of professional qualifications. Available at: http://www.aic.lv/bolona/Recognition/dir prof/ Directive 200536 EC.pdf [15. 11.2015].

European Commission, 2015. Nurse forecasting: human resources planning in nursing (RN4CAST). (2009-2011). Available at:

http://cordis.europa.eu/project/rcn/91239 en.html [15. 11. 2015].

International Council of Nurses, 2015. Declaration (Opatija, Croatia, 15. October 2015).

Cite as/Citirajte kot:

Shamian, J. \& Požun, P., 2015. No health without workforce, no workforce without nurses and midwifes. Obzornik zdravstvene nege, 49(4), pp. 256-259. http://dx.doi.org/10.14528/snr.2015.49.4.77 